\title{
Influence of weather variables on methane and carbon dioxide flux from a shallow pond
}

Sivakiruthika Natchimuthu, Balathandayuthabani Panneer Selvam and David Bastviken

\section{Linköping University Post Print}

\section{Tweet}

N.B.: When citing this work, cite the original article.

The original publication is available at www.springerlink.com:

Sivakiruthika Natchimuthu, Balathandayuthabani Panneer Selvam and David Bastviken, Influence of weather variables on methane and carbon dioxide flux from a shallow pond, 2014, Biogeochemistry, (119), 1-3, 403-413.

http://dx.doi.org/10.1007/s10533-014-9976-z

Copyright: Springer Verlag (Germany)

http://www.springerlink.com/?MUD=MP

Postprint available at: Linköping University Electronic Press

http://urn.kb.se/resolve?urn=urn:nbn:se:liu:diva-107440 
Influence of weather variables on methane and carbon dioxide flux from a shallow pond

Sivakiruthika Natchimuthu, Department of Thematic Studies - Water and Environmental Studies, Linköping University, 58183 Linköping, Sweden. E-mail: sivakiruthika.natchimuthu@liu.se, phone number: +4613282959 (Corresponding author).

Balathandayuthabani Panneer Selvam, Department of Thematic Studies - Water and Environmental Studies, Linköping University, 58183 Linköping, Sweden. Now at Department of Physical Geography and Ecosystem Science, Sölvegatan 12, Lund University, 22362 Lund, Sweden.

David Bastviken, Department of Thematic Studies - Water and Environmental Studies, Linköping University, 58183 Linköping, Sweden. 


\section{Abstract}

Freshwaters are important sources of the greenhouse gases methane $\left(\mathrm{CH}_{4}\right)$ and carbon dioxide $\left(\mathrm{CO}_{2}\right)$ to the atmosphere. Knowledge about temporal variability in these fluxes is very limited, yet critical for proper study design and evaluating flux data. Further, to understand the reasons for the variability and allow predictive modeling, the temporal variability has to be related to relevant environmental variables. Here we analyzed the effect of weather variables on $\mathrm{CH}_{4}$ and $\mathrm{CO}_{2}$ flux from a small shallow pond during a period of four months. Mean $\mathrm{CH}_{4}$ flux and surface water $\mathrm{CH}_{4}$ concentration were 8.0 [3.3 to 15.1$] \pm 3.1 \mathrm{mmol} \mathrm{m}^{-2} \mathrm{~d}^{-1}$ (mean [range] $\pm 1 \mathrm{SD}$ ) and 1.3 [0.3 to 3.5] $\pm 0.9 \mu \mathrm{M}$ respectively. Mean $\mathrm{CO}_{2}$ flux was 1.1 [-9.8 to 16.0$] \pm 6.9 \mathrm{mmol} \mathrm{m}^{-2} \mathrm{~d}^{-1}$. Substantial diel changes in $\mathrm{CO}_{2}$ flux and surface water $\mathrm{CH}_{4}$ concentration were observed during detailed measurements over a 24 hour cycle. Thus diel patterns need to be accounted for in future measurements. Significant positive correlations of $\mathrm{CH}_{4}$ emissions with temperature were found and could include both direct temperature effects as well as indirect effects (e.g. related to the growth season and macrophyte primary productivity providing organic substrates). $\mathrm{CO}_{2}$ flux on the other hand was negatively correlated to temperature and solar radiation, presumably because $\mathrm{CO}_{2}$ consumption by plants was higher relative to $\mathrm{CO}_{2}$ production by respiration during warm sunny days. Interestingly, $\mathrm{CH}_{4}$ fluxes were comparable to ponds with similar morphometry and macrophyte abundance in the tropics. We therefore hypothesize that $\mathrm{CH}_{4}$ and $\mathrm{CO}_{2}$ summer emissions from ponds could be more related to the morphometry and dominating primary producers rather than latitude per se. Data indicate that $\mathrm{CH}_{4}$ emissions, given the system characteristic frameworks, is positively affected by increased temperatures or prolonged growth seasons.

Key words: $\mathrm{CH}_{4}$ flux; $\mathrm{CO}_{2}$ flux; surface water $\mathrm{CH}_{4}$ concentration; pond; diel variability; weather; temperature. 


\section{Introduction}

Methane $\left(\mathrm{CH}_{4}\right)$ and carbon dioxide $\left(\mathrm{CO}_{2}\right)$ are important greenhouse gases (GHG) with substantially increased levels in the Earth's atmosphere during the last centuries (Denman et al. 2007). Lakes and ponds have an important role in carbon cycling in spite of occupying a small area on the Earth (Downing 2009). Recent estimates say that inland freshwaters could be emitting $0.65 \mathrm{Pg}$ of $\mathrm{C}$ (as $\mathrm{CO}_{2}$ equivalents) $\mathrm{yr}^{-1}$ in the form of $\mathrm{CH}_{4}$ (Bastviken et al. 2011) and $1.4 \mathrm{Pg}_{\text {of }} \mathrm{C}\left(\mathrm{CO}_{2} \mathrm{eq}\right) \mathrm{yr}^{-1}$ in the form of $\mathrm{CO}_{2}$ (Tranvik et al. 2009), i.e. in total more than $2 \mathrm{Pg} \mathrm{C}\left(\mathrm{CO}_{2}\right.$ eq) $\mathrm{yr}^{-1}$. This is substantial when compared with the global land sink of 2.6 $\mathrm{Pg}_{\text {of }} \mathrm{C} \mathrm{yr}^{-1}$ (Denman et al. 2007). Thus inland waters are important sources of greenhouse gases. An analysis of global lakes and impoundments by Downing et al. (2006) concluded that smaller aquatic systems occupy a larger area than previously believed. It has also been suggested that small aquatic systems have higher rates of $\mathrm{CH}_{4}$ and $\mathrm{CO}_{2}$ emissions per unit area (Michmerhuizen et al. 1996; Bastviken et al. 2004; Kortelainen et al. 2006; Juutinen et al. 2009). Various climate feed-backs on aquatic $\mathrm{CH}_{4}$ and $\mathrm{CO}_{2}$ fluxes have been suggested based on how, for example, hydrology (Ranthakari and Kortelainen 2005; Battin et al. 2009; Kosten et al. 2010) and temperature (Segers 1998; Van Hulzen et al. 1999; Flanagen and Mccauley 2008; Duc et al. 2010; Gudasz et al. 2010; Kosten et al. 2010) influence GHG formation, consumption, and transport. However, available datasets does not allow the evaluation of climate change effects on the emission of $\mathrm{CH}_{4}$ and $\mathrm{CO}_{2}$ from inland waters. In fact, repeated measurements of $\mathrm{CH}_{4}$ fluxes from the same aquatic systems are very rare so far, with the study of Utsumi et al. (1998) and Xing et al. (2005) being some of few exceptions. In addition $\mathrm{CO}_{2}$ emissions are frequently estimated from concentration or $\mathrm{pCO}_{2}$ measurements and direct flux measurements, as well as repeated measurements are rare. The few studies that consider temporal variability often rely on short term (30 min) measurements at, for example, monthly intervals. To evaluate the representativeness of such approaches the short-term (e.g. diel and day-to-day) variability is important. Only a few studies have reported diel variations in $\mathrm{CH}_{4}$ and $\mathrm{CO}_{2}$ fluxes (Mattson and Likens 1990; Hamilton et al. 1994; Sellers et al. 1995; Bastviken et al. 2004, 2010; Huotari et al. 2009). Additional studies of variability between days-weeks would be very valuable to understand and predict how rapidly fluctuating environmental variables affect GHG fluxes 
from inland waters (beyond the connection between air pressure changes and $\mathrm{CH}_{4}$ ebullition; e.g. Mattson and Likens 1990).

Meteorological variables such as temperature, pressure, solar radiation and precipitation can change over timescales of minutes to seasons and hence we hypothesize that they affect emissions. Because of the importance of small aquatic systems as dominant aquatic system category and high emitters per unit area, and because such systems are often shallow and well mixed allowing rapid changes in water and sediment following the weather, we tested this hypothesis by comparing $\mathrm{CH}_{4}$ and $\mathrm{CO}_{2}$ flux measurements from a shallow pond with locally collected weather variables. Temperature, which was of primary interest, can change quickly in air but responds more slowly (hours to days) in water environments. We chose to focus on timescales of days to primarily study temporal variability which was faster than, for example, seasonal changes in temperature or methanogenesis substrate availability but still slow enough to allow temperature changes in water and sediments. Additionally, this study illustrates the magnitude of the diel variations in the concentrations of $\mathrm{CH}_{4}$ and $\mathrm{CO}_{2}$ fluxes in this pond.

\section{Methods}

\subsection{Study site}

The study was conducted in a small shallow pond $\left(15^{\circ} 34^{\prime} 44 " \mathrm{E}, 58^{\circ} 23^{\prime} 37^{\prime \prime} \mathrm{N}\right)$ located near Linköping University, Linköping, Sweden, from $21^{\text {st }}$ June to $10^{\text {th }}$ October 2010 . The periods with frequent measurements were from $21^{\text {st }}$ June to $18^{\text {th }}$ August with additional measurements in September and October. The average depth of the pond was $1.2 \mathrm{~m}$ and its area was approximately $1200 \mathrm{~m}^{2}$. The pond had an inflow and an outflow and was a part of a system of ponds and streams in a park area. The water level was regulated and maintained constant throughout the measurement period. The pond and stream system had an average flow through of $0.8 \mathrm{~m}^{3} \mathrm{~min}^{-1}$ resulting in an average residence time of 2 hours in the studied pond. Hence, the water was always well mixed by continuous water flow through the system. The pond had a high abundance of aquatic macrophytes including Phragmites australis, 
Typha latifolia and Potamogeton sp. The air temperature during the study period ranged from 0 to $33^{\circ} \mathrm{C}$.

\subsection{Flux measurements}

$\mathrm{CH}_{4}$ and $\mathrm{CO}_{2}$ flux were measured using floating chambers similar to those described by Bastviken et al. (2010) and shown to not bias fluxes (relative to $\mathrm{SF}_{6}$ gas transfer measurements; Cole et al. 2010). The chambers were made of plastic buckets of $7.5 \mathrm{~L}$ volume with Styrofoam floating collars. Each chamber was covered with aluminium tape to reflect the sunlight to minimize internal heating. Transparent PVC tubings (length 20-25 cm, outer diameter 5mm and inner diameter 3mm) fitted with 3-way luer-lock stopcocks (Becton-Dickinson) were used for transferring gas samples from the chamber into plastic syringes (Becton-Dickinson).

\subsection{1. $\mathrm{CH}_{4}$ flux}

Six to seven chambers were attached to two ropes across the pond. Thereby chambers could be accessed without a boat by gently pulling them towards the shore upon sampling. The depths of water under the chambers were $0.2,0.3,0.6,0.9,1.0,1.4$ and $2.5 \mathrm{~m}$. The chambers covered open water between the plants and measurements did not focus on flux through plants. Our goal was to study open water fluxes including diffusive flux and ebullition which is often considered the largest flux type from inland waters. Hence no plant-mediated flux measurements were made and we report open water fluxes only. Upon chamber deployment, initial gas samples were taken from each chamber and final samples were collected after 24,48 or 72 hours. The deployment time did not significantly affect emission rates (see also results). Plastic syringes of $60 \mathrm{ml}$ capacity fitted with 3-way valves were used to collect samples. Before sampling, the gas inside the chambers was mixed by pumping the syringe three times when it was attached. About $50 \mathrm{ml}$ of gas samples were collected and all the sample syringes were immediately transferred to an insulated plastic container and analyzed within five hours. A total of $108 \mathrm{CH}_{4}$ flux measurements were made. 
A simple calculation of flux by dividing the change in $\mathrm{CH}_{4}$ concentration in the chamber by the area and the time underestimates the flux slightly (up to $10 \%$ over a 24 hour period) (Bastviken et al. 2010). Total flux into the chamber through diffusion and ebullition was therefore calculated by the method described by Bastviken et al. (2004) to correct for gradually decreasing diffusive flux with time. Briefly, diffusive flux of $\mathrm{CH}_{4}$ into the chamber can be described by the equation,

$$
F=k\left(C_{w}-C_{f c}\right)
$$

where $\mathrm{F}$ is the flux in moles $\mathrm{m}^{-2} \mathrm{~d}^{-1}, k$ is the piston velocity in $\mathrm{m} \mathrm{d}^{-1}, \mathrm{C}_{\mathrm{w}}$ is the measured $\mathrm{CH}_{4}$ concentration in water in moles $\mathrm{m}^{-3}$ and $\mathrm{C}_{\mathrm{fc}}$ is the concentration of $\mathrm{CH}_{4}$ in water if it were in equilibrium with the $\mathrm{CH}_{4}$ concentration in the floating chamber. $k$ was calculated for each chamber during a deployment period by solving Equation 1 as explained in detail in Bastviken et al. (2004) (concentrations were measured as described below). The ratio of each $k$ value to the minimum $k$ of each specific deployment period was obtained. From the frequency distribution of this ratio, a ratio of two was taken as the cut-off point, by which the chambers having values above two were considered to have received ebullition while the chambers having $k$ values near the minimum $k$ of the period were considered to have primarily received diffusive flux (see Bastviken et al. (2004) for a detailed description).

\subsection{2. $\mathrm{CO}_{2}$ flux}

For measuring $\mathrm{CO}_{2}$ flux, two separate chambers were deployed and five gas samples were taken once every seven minutes from each of them. $\mathrm{CO}_{2}$ flux was calculated using rates of change of $\mathrm{CO}_{2}$ (ppm/min) obtained through linear regression of the five repeated measurements versus time and divided by the chamber area. $\mathrm{CO}_{2}$ is not typically emitted by ebullition because it is highly soluble in water, hence $\mathrm{CO}_{2}$ flux was assumed to be primarily diffusive. Given the well mixed conditions we also assume small spatial variability for $\mathrm{CO}_{2}$ fluxes. 


\subsection{Surface water $\mathrm{CH}_{4}$ concentration}

Samples for measuring $\mathrm{CH}_{4}$ concentrations in the surface water were taken as described by Bastviken et al. (2010), to estimate diffusive flux and ebullition as described above. A $60 \mathrm{ml}$ syringe with a 3way valve was used to draw water from about $6-10 \mathrm{~cm}$ below water surface. A portion of water was used to remove air and then a new portion of about $45 \mathrm{ml}$ of water was drawn into the syringe. The water volume was adjusted to $40 \mathrm{ml}$ and then $20 \mathrm{ml}$ of air was added while holding the syringe above head to avoid contamination by breath. The syringe now holding $40 \mathrm{ml}$ water and $20 \mathrm{ml}$ headspace was closed and shaken for at least 1 min for gas equilibration. The headspace gas was then retained for analysis. Air samples were also collected in order to correct for the concentration of $\mathrm{CH}_{4}$ already present in the $20 \mathrm{ml}$ air introduced as headspace. After analyzing the headspace concentration, the water concentration was calculated using Henry's Law adjusted for temperature (Wiesenburg and Guinasso 1979). The concentration of $\mathrm{CH}_{4}$ in water was calculated as the total moles of $\mathrm{CH}_{4}$ in the headspace and the water phase minus the initial amount from the added air, and then divided by the water volume. Upon the water-headspace equilibration in the syringe, the water temperature will transfer to the headspace temperature and therefore the water temperature was assumed to represent both gas and water phases and used for calculating surface water $\mathrm{CH}_{4}$ concentrations.

At most sampling occasions mid-day (12:00-15:00) measurements of $\mathrm{CO}_{2}$ fluxes were performed. Additional diel measurements were done over a 24 hour period from 18:00 on August 17 to 18:00 on August 18, 2010 to observe the diel changes in $\mathrm{CH}_{4}$ and $\mathrm{CO}_{2}$. Samples of $\mathrm{CH}_{4}$ flux, surface water $\mathrm{CH}_{4}$ concentration and $\mathrm{CO}_{2}$ flux were collected once every four hours approximately.

\subsection{Other measurements and data}

Air temperature, water temperature (accuracy $0.1^{\circ} \mathrm{C}$ ) and atmospheric pressure were noted during the sampling occasions. All the gas samples were analyzed using a gas chromatography (Agilent Technologies, 7890A) equipped with a $1.8 \mathrm{~m} \times 3.175 \mathrm{~mm}$ Porapak Q 80/100 column from Supelco, a methanizer, and a flame ionization detector (FID). Certified standards of $100 \pm 2 \mathrm{ppm}\left(\mathrm{CH}_{4}, \mathrm{CO}_{2}\right)$, 
$1000 \pm 20 \mathrm{ppm}\left(\mathrm{CH}_{4}, \mathrm{CO}_{2}\right), 1 \pm 0.02 \% \mathrm{CO}_{2}$ and $2 \pm 0.02 \% \mathrm{CH}_{4}$ were used for calibrating our samples during analysis.

Weather data for the period June-October 2010 was obtained from a Davis Vantage Pro2 Plus weather station of Linköping University, which was situated $200 \mathrm{~m}$ from the studied pond. Hourly data of temperature $\left({ }^{\circ} \mathrm{C}\right)$, solar radiation (hourly integrated values of sum of global direct and diffuse solar irradiance in $\mathrm{W} \mathrm{m}^{-2}$ measured with a pyramometer), precipitation (mm) and pressure (hPa) for the above period was used for the study. Wind speed data was obtained from a meteorological station at Malmslätt, 3 km North West from the pond. Relationships between gas fluxes or concentrations with mean, maximum, minimum and change in pressure, solar radiation, precipitation, and air temperature during measurement period and water temperature during sampling were analyzed. Fluxes of $\mathrm{CH}_{4}$ were compared with the above variables calculated for the full period of deployment of the chamber. For $\mathrm{CH}_{4}$ water concentration and $\mathrm{CO}_{2}$ flux (which concern a shorter time period of integration) weather data nearest to the sampling time and 24 hour data before sampling was used. Daily average temperature data for the years 1983 - 2012 during the period $21^{\text {st }}$ June to $10^{\text {th }}$ October showed that the study period of 2010 had a mean temperature similar to majority of the other years. Hence, our results were not biased by extreme weather conditions.

\subsection{Analysis of data}

All data were checked for normality. Data from all the chambers used for $\mathrm{CH}_{4}$ and $\mathrm{CO}_{2}$ flux, respectively, were used in the analysis. For data that were normally distributed, Pearson's correlations and simple linear regressions were used to study the relationships. For skewed data, nonparametric Kendall's $\tau$ and Kendall-Theil Robust Line were used. The latter is an effective alternative to ordinary least squares regression if the data has influential points and outliers and it eliminates the need to delete such extreme points that can be very important for total fluxes over time (Helsel and Hirsch 2002). Multiple regressions were also tried for relevant combinations of variables but because none of these were statistically significant only bivariate correlations and regressions will be discussed below. All analyses were done using IBM SPSS 19 for windows and the Kendall-Theil Robust Line Program 
version 1.0 from the U. S. Geological Survey (Granato 2006). Non-parametric Kruskal-Wallis test was used to examine differences in $\mathrm{CH}_{4}$ concentration and $\mathrm{CO}_{2}$ flux during diel sampling. In this case, the $\mathrm{CH}_{4}$ concentration is seen as a component of the diffusive flux. Using two chambers only in the diel study, the frequent ebullition made it difficult to resolve diffusive flux with the direct flux measurements which was why the concentrations were used. There was no clear diel pattern in the total $\mathrm{CH}_{4}$ flux including the highly variable ebullition during the study period. Therefore diel variability is reported for surface water $\mathrm{CH}_{4}$ concentration and $\mathrm{CO}_{2}$ flux only.

\section{Results}

\section{1. $\mathrm{CH}_{4}$ flux and concentrations}

The mean total open water flux of $\mathrm{CH}_{4}$ over the 49 days measured was 8.0 [3.3 to 15.1] $\pm 3.1 \mathrm{mmol} \mathrm{m}^{-}$ ${ }^{2} \mathrm{~d}^{-1}$ (mean [range] $\pm 1 \mathrm{SD}$ ). Fluxes were higher in mid-July and lower flux was observed in September (Fig. 1). Diffusive fluxes were typically in the range of 0.1 to $1.45 \mathrm{mmol} \mathrm{m}^{-2} \mathrm{~d}^{-1}$. On two occasions with higher surface water $\mathrm{CH}_{4}$ concentrations, high diffusive fluxes (2.2 and $3.6 \mathrm{mmol} \mathrm{m}^{-2} \mathrm{~d}^{-1}$ ) were noted.

Total $\mathrm{CH}_{4}$ flux was positively correlated with mean air temperature, maximum air temperature, mean solar radiation during the period of deployment and water temperature at the time of sampling $(r=$ 0.69, 0.58, 0.47 and 0.61, $p<0.05$; see Fig. 2 and Table 1). However, neither total $\mathrm{CH}_{4}$ flux nor diffusive flux was correlated with wind speed.

About $91 \%$ of the total flux occurred through ebullition and was also correlated with mean air temperature, maximum air temperature, mean solar radiation during the period of deployment and water temperature at the time of sampling ( $r=0.67,0.65,0.54$ and $0.62, p<0.05$; see Table 1$)$. Mean ebullition ( $\mathrm{n}=89$; where $\mathrm{n}$ is the number of observations with ebullition) recorded was 7.6 [3.1 to 11.6] $\pm 2.8 \mathrm{mmol} \mathrm{m}^{-2} \mathrm{~d}^{-1}$. No significant correlation was found between deployment period and diffusive, ebullitive or total flux ( $p=0.66,0.48$ and 0.37 respectively). During the sampling period from 16 to 17 September we observed the lowest $\mathrm{CH}_{4}$ flux $\left(3.3 \mathrm{mmol} \mathrm{m}^{-2} \mathrm{~d}^{-1}\right)$ and the lowest 
temperatures. To check how much this specific data point affected the temperature relationships, a correlation analysis after excluding this point was made which also showed a significant air temperature relation with total $\mathrm{CH}_{4}$ flux and ebullition ( $r=0.63$ and 0.62 respectively; $p<0.01$; for regression analysis, and $\mathrm{R}^{2}$ values see Fig. 2).

The mean $\mathrm{CH}_{4}$ concentration in the surface water $(\mathrm{n}=47)$ was $1.3[0.3$ to 3.5$] \pm 0.9 \mu \mathrm{M}$. $\mathrm{CH}_{4}$ water concentration was negatively correlated with mean pressure, mean solar radiation, water temperature and mean air temperature (Table 1). It was also positively correlated with the maximum precipitation 24 hours before the time of sampling (Kendall's $\tau=0.25, p=0.022$ ). Diel measurements revealed that surface water $\mathrm{CH}_{4}$ concentration showed a distinct diel variability with significant differences between sampling times ( $p=0.003$; Fig. 3). The $\mathrm{CH}_{4}$ concentrations increased from $0.4 \mu \mathrm{M}$ (mean; $\mathrm{n}=3$ ) at 22:00 to $2.2 \mu \mathrm{M}$ at 14:00 which corresponds to about 4.5-fold increase. Diel variation of $\mathrm{CH}_{4}$ concentration was not correlated with water temperature, pressure or wind speed, but it was positively correlated with solar radiation $(r=0.80, p<0.000)$.

\section{2. $\mathrm{CO}_{2}$ flux}

$\mathrm{CO}_{2}$ flux showed the expected diel variability with higher values at night. During the 24 hour sampling, $\mathrm{CO}_{2}$ flux changed from -6.4 (mean; $\mathrm{n}=2$ ) $\mathrm{mmol} \mathrm{m}^{-2} \mathrm{~d}^{-1}$ at 14:00 to $31.8 \mathrm{mmol} \mathrm{m}^{-2} \mathrm{~d}^{-1}$ at 06:00 (Fig. 3), which is a 6-fold change. Diel $\mathrm{CO}_{2}$ flux was negatively correlated with air temperature, water temperature and solar radiation $(r=-0.87,-0.71$ and $-0.78, p<0.01)$.

The mean $\mathrm{CO}_{2}$ flux $(\mathrm{n}=27)$ was $1.1[-9.8$ to 16.0$] \pm 6.7 \mathrm{mmol} \mathrm{m}^{-2} \mathrm{~d}^{-1}$ and the median value was -0.55 mmol m $\mathrm{m}^{-2} \mathrm{~d}^{-1}$. The $\mathrm{CO}_{2}$ flux levels were generally lower in summer months of June and July and started to increase in August. $\mathrm{CO}_{2}$ flux was negatively correlated with water temperature, air temperature and solar radiation ( $r=-0.57,-0.53$ and -0.59 respectively; $p<0.01$; Fig. 4 ), but was not correlated with wind speed. 


\section{Discussion}

$\mathrm{CH}_{4}$ fluxes from this study were high and are comparable to the $\mathrm{CH}_{4}$ fluxes of 3.2 to $5.1 \mathrm{mmol} \mathrm{m}^{-2} \mathrm{~d}^{-1}$ from eutrophic lakes of Kevätön and Postilampi in Finland (Huttunen et al. 2003), and with shallow and macrophyte rich tropical systems (in the order of $8 \mathrm{mmol} \mathrm{m}^{-2} \mathrm{~d}^{-1}$; e.g. Bastviken et al. 2010). Fluxes from larger water bodies in boreal and temperate biomes were usually lower than $2 \mathrm{mmol} \mathrm{m} \mathrm{m}^{-2}$ $\mathrm{d}^{-1}$ (Bastviken et al. 2011). Surface water $\mathrm{CH}_{4}$ concentration values correspond well with the other studies done in Sweden (Bastviken et al. 2004). Altogether this indicates that system characteristics including depth, productivity and macrophyte abundance can be more important for $\mathrm{CH}_{4}$ fluxes than the latitude (e.g. average yearly temperature) per se and the degree of response to weather and climate variables probably depends on these system characteristics.

Ebullition is increasingly recognized to play a major role for $\mathrm{CH}_{4}$ flux from inland waters (Huttunen et al. 2003; Bastviken et al. 2011). Ebullition has been estimated to account for $40-60 \%$ of total flux in lakes and ebullition is facilitated by lesser water column height which leads to a lower hydrostatic pressure on bubbles (Bastviken et al. 2004). Thus, 91\% of $\mathrm{CH}_{4}$ flux as ebullition from this shallow pond is consistent with previous findings (Bastviken et al. 2004; Walter et al. 2006; Bastviken et al. 2010).

The day time $\mathrm{CO}_{2}$ fluxes were mostly negative during the peak productive summer months because of photosynthesis while the pond emitted $\mathrm{CO}_{2}$ at night and after the summer when organic matter degradation dominated over primary production.

In this study, correlations were found between $\mathrm{CH}_{4}$ emission and temperature variables. Variations in mean air temperature for instance explained as much as $47 \%$ of the variation in total flux and $45 \%$ of the variation in ebullition. Methanogenesis is highly temperature dependent (Segers 1998; Van Hulzen et al. 1999), and increase in temperature was observed to be positively influencing the $\mathrm{CH}_{4}$ production in sediments in laboratory experiments (Liikanen et al. 2002; Duc et al. 2010). $\mathrm{CH}_{4}$ emission peaks in summer and positive correlations of $\mathrm{CH}_{4}$ emissions with air and water temperature were found in a shallow subtropical lake in China (Xing et al. 2005). High emissions of $\mathrm{CH}_{4}$ coincided with air 
temperature peaks in littoral zones of two east Antarctic lakes (Zhu et al. 2010). Altogether, this suggests that temperature affect $\mathrm{CH}_{4}$ emissions not only in experiments but also under field conditions. In our case, the $\mathrm{CH}_{4}$ flux was more strongly correlated with air temperatures than with water temperatures (Fig. 2). A likely reason for this is that we had hourly values of air temperature enabling robust integration over the actual deployment periods, while the water temperatures were measured when chamber deployments were started or stopped only, not properly reflecting the whole deployment period. Probably, high frequency measurements of water temperatures would have been at least as strongly correlated with fluxes as air temperature.

The apparent relationship between temperature and $\mathrm{CH}_{4}$ flux is associated with several questions. Firstly, it is known that in many systems a large proportion of the produced $\mathrm{CH}_{4}$ is oxidized before being emitted and methane oxidation has not shown any temperature dependence but rather a strong substrate limitation. Therefore, a temperature dependence on flux is more likely in (1) a system where ebullition is the dominating flux pathway because ebullition largely escapes methane oxidation and is more likely to be directly related to methane production rates in sediments, and (2) where the ebullition is generated in surficial sediments where temperatures fluctuate more than in deep sediments. Secondly, it is not yet clear if any of the temperature-flux relationships proposed (here or in the previous literature) can be separated from seasonal effects, i.e. greater availability of easily available substrates for methanogenesis during peak growth season with high macrophyte primary productivity which typically coincides with high temperatures and solar radiation. Our study, with high frequency flux measurements including day-to-day variability, presumably being less influenced by seasonal macrophyte primary productivity, may have a higher probability of detecting direct temperature effects than studies using less frequent measurements (e.g. monthly 30 min measurements), but still we cannot exclude that a significant part of our temperature-flux relationship is in fact driven by seasonal substrate supply effects. We did not find any relationship between $\mathrm{CH}_{4}$ flux and wind speed and this is probably because (1) the $\mathrm{CH}_{4}$ flux from this pond was dominated by ebullition (2) lack of local wind speed data near the water surface of the pond (3) this is a flow through 
system in a stream network with a short residence time and a baseline mixing due to the water flow which may also partly disconnect fluxes from wind speed.

The observed diel variations in surface water $\mathrm{CH}_{4}$ concentrations (Fig. 3) were consistent with previous studies (Bastviken et al. 2004, Bastviken et al. 2010) noting lower emissions or concentrations during the dark period when compared to daytime. This was attributed to the relatively calm, less windy conditions at night suggesting that higher wind and water turbulence during daytime will cause an increased exchange of $\mathrm{CH}_{4}$ across the sediment-water interface resulting in elevated concentrations and fluxes. If there were more pronounced mixing during daytime this could have resulted in a larger transport of $\mathrm{CH}_{4}$ from sediment pore water to surface water. We did not find a statistically significant relationship between wind speed and $\mathrm{CH}_{4}$ concentration, but during the diel study the wind speeds were generally lower at night. The fact that gas exchange of $\mathrm{CH}_{4}$ seemed disconnected from wind speed in our systems makes it difficult to know the role of the wind in this case. Alternatively, $\mathrm{CH}_{4}$ concentrations in the water might have been affected by light induced active gas transport through emergent plants (Van der Nat et al. 1998) and subsequent leakage from plant stems to the water. Another possibility is increased root leakage of substrates for methanogenesis during daytime. The opposite diel patterns has been observed in a deeper wind-sheltered tropical lake which became stratified and accumulated $\mathrm{CH}_{4}$ in anoxic bottom water during daytime, while nighttime convection transported the accumulated $\mathrm{CH}_{4}$ to the surface waters resulting in elevated night-time emissions (Crill et al. 1988). It has been suggested that methanotrophs could be inhibited by light (Dumestre et al. 1999; Murase and Sugimoto 2005) but presumably this would have a limited effect on methane oxidation in surface sediments. The results from this study and the literature show that diel patterns in $\mathrm{CH}_{4}$ concentrations and diffusive fluxes cannot be ignored.

Many previous studies have found significant amount of ebullition coinciding with a low air pressure (Mattson and Likens 1990; Casper et al. 2000). Though we did not find a statistically significant relationship, higher rates of $\mathrm{CH}_{4}$ ebullition were generally observed in this study when the air pressure drop was steep. A possible effect of passing low pressures or high wind events was also indicated by 
the negative correlations between $\mathrm{CH}_{4}$ concentration and temperature, solar radiation and atmospheric pressure, respectively, which suggest that the concentration increased when the weather conditions were cloudy and passing low pressures with associated wind and rain triggered $\mathrm{CH}_{4}$ release from sediments.

$\mathrm{CO}_{2}$ fluxes were found to be negatively correlated with water temperature in this pond, in contrast to few studies which found a positive relationship. Studies which compared $\mathrm{pCO}_{2}$ and water temperature among many lakes have found a positive relationship (Marotta et al. 2009; Kosten et al. 2010). The difference between these and our study could be because we followed $\mathrm{CO}_{2}$ over time in one system. Our data for $\mathrm{CO}_{2}$ including the negative correlations between daytime flux and temperature (Table 1), indicate indirect regulation by the balance between photosynthesis and respiration in any given system over time. Such day-to-day effects with higher photosynthesis and daytime $\mathrm{CO}_{2}$ uptake during sunny (and thereby warmer) days than during more cloudy days seem logical. Photosynthesis was also extensive in relation to respiration during the summer months and consumed a lot of $\mathrm{CO}_{2}$ resulting in under-saturation, until the macrophytes started to die off after August. A marked increase in the daytime emission of $\mathrm{CO}_{2}$ was observed after August. This indicates an additional seasonal control of $\mathrm{CO}_{2}$ emissions, together with the diel and day-to-day effects. A similar negative correlation of $\mathrm{CO}_{2}$ fluxes with air and water temperature has been observed before (Xing et al. 2005) which was attributed to higher primary production during summer months. $\mathrm{CO}_{2}$ flux was not correlated with wind speed and a likely reason could be that the $\mathrm{CO}_{2}$ flux was strongly controlled by the primary production in the pond, apart from the reasons mentioned previously.

$\mathrm{CO}_{2}$ flux showed a distinct diel pattern when measurements were done over a 24 hour period (Fig. 3). During the dark period of the day $\mathrm{CO}_{2}$ flux was markedly higher, most likely linked to the domination of respiration over photosynthesis during the dark period of the day. Consequently sampling during the day time may greatly underestimate the actual values. Based on the 24 hour period when we did the diel study, the daytime $\mathrm{CO}_{2}$ flux (at 14:00) was $-6.4 \mathrm{mmol} \mathrm{m}^{-2} \mathrm{~d}^{-1}$, while the integrated 24 hour flux was $13.4 \mathrm{mmol} \mathrm{m}^{-2} \mathrm{~d}^{-1}$. Thereby a system rich in plant biomass being a net $\mathrm{C}$ sink during day-time 
can be a net source of carbon when considering a full 24 hour cycle. $\mathrm{CO}_{2}$ concentrations were higher in the night and lower in the day in some ponds of the Hudson Bay Lowlands (Hamilton et al. 1994). In a study by Sellers et al (1995), higher $\mathrm{CO}_{2}$ concentrations were recorded around 09:00, followed by lower values around 20:00 and it was demonstrated that more frequent sampling is necessary. Diel changes in $\mathrm{CO}_{2}$ concentration was reported in a Finnish lake and the importance of accounting for diel changes has been emphasized in a study by Huotari et al (2009). The lack of full diel coverage of $\mathrm{CO}_{2}$ in this case (except during one occasion) prevents making an overall $\mathrm{CO}_{2}$ balance. However, it is clearly necessary to account for diel variability to constrain aquatic $\mathrm{CO}_{2}$ fluxes and carbon balances.

\section{Conclusion}

This small shallow pond emitted $8.0 \mathrm{mmol} \mathrm{m}^{-2} \mathrm{~d}^{-1}$ of $\mathrm{CH}_{4}$, comparable to tropical aquatic systems, which shows that characteristics of the ecosystem may be more important than the latitude. Data from this study indicates that such small shallow systems should be studied and included in greenhouse gas estimates and excluding such environments could lead to underestimated emissions also at high latitudes. This study indicates a positive correlation between warmer weather and $\mathrm{CH}_{4}$ fluxes. This effect can be explained in multiple ways, including via direct effects of increased temperatures and indirect effects from prolonged growth seasons and thereby supply of suitable substrates for $\mathrm{CH}_{4}$ production. Regardless of the underlying reason our data show that positive warming feed-backs on aquatic $\mathrm{CH}_{4}$ fluxes are likely. Increased frequency of passing low pressures and rain storms may facilitate the transport of $\mathrm{CH}_{4}$ from sediments to the atmosphere and reduce the amount of time available for methane oxidation.

This study also indicates the importance of measuring $\mathrm{CO}_{2}$ emissions from shallow aquatic systems for extended periods to account for diel variability and covering different seasons and night time emissions seem particularly important. Clearly, the climate feedback on $\mathrm{CO}_{2}$ fluxes will be highly dependent on the balance between primary production and respiration. Elevated $\mathrm{CO}_{2}$ emissions have been proposed due to increased sediment respiration at higher temperatures (Gudasz et al. 2010) and 
because of indirect effects such as precipitation (Rantakari and Kortelainen 2005). In addition, seasonal effects add to this with expected longer periods with high primary productivity.

\section{Acknowledgements}

We thank Henrik Reyier for his help in sampling and analysis of this study. Magnus Öhrman and Ulf Jacobsson from Akademiska Hus kindly provided the weather data and the information about the studied pond.

\section{References}

Bastviken D, Cole J, Pace M, Tranvik L (2004) Methane emissions from lakes: Dependence of lake characteristics, two regional assessments, and a global estimate. Glob Biogeochem Cycle 18 (4):GB4009

Bastviken D, Santoro AL, Marotta H, Pinho LQ, Calheiros DF, Crill P, Enrich-Prast A (2010) Methane Emissions from Pantanal, South America, during the Low Water Season: Toward More Comprehensive Sampling. Environ Sci Technol 44 (14):5450-5455

Bastviken D, Tranvik LJ, Downing JA, Crill PM, Enrich-Prast A (2011) Freshwater Methane Emissions Offset the Continental Carbon Sink. Science 331 (6013):50-50

Battin TJ, Luyssaert S, Kaplan LA, Aufdenkampe AK, Richter A, Tranvik LJ (2009) The boundless carbon cycle. Nat Geosci 2 (9):598-600

Casper P, Maberly SC, Hall GH, Finlay BJ (2000) Fluxes of methane and carbon dioxide from a small productive lake to the atmosphere. Biogeochemistry 49 (1):1-19

Cole JJ, Bade DL, Bastviken D, Pace ML, Van dB (2010) Multiple approaches to estimating air-water gas exchange in small lakes. Limnol Oceanogr Methods 8: 285-293

Crill PM, Bartlett KB, Wilson JO, Sebacher DI, Harriss RC, Melack JM, MacIntyre S, Lesack L (1988) Tropospheric methane from an Amazonian floodplain lake. J Geophys Res 93: 15641570

Denman KL, Brasseur G, Chidthaisong A, Ciais P, Cox PM, Dickinson RE, Hauglustaine D, Heinze C, Holland E, Jacob D, Lohmann U, Ramachandran S, da Silva Dias PL, Wofsy SC, Zhang X 
(2007) Couplings Between Changes in the Climate System and Biogeochemistry. In: Solomon S, Qin D, Manning M et al. (eds) Climate Change 2007: The Physical science basis. Contribution of Working Group I to the Fourth Assessment Report of the Intergovernmental panel on Climate Change. Cambridge University Press, Cambridge, pp 499-588

Downing JA (2009) Global Limnology: up-scaling aquatic services and processes to planet Earth. Verh Internat Verein Limnol 30 (8):1149-1166

Downing JA, Prairie YT, Cole JJ, Duarte CM, Tranvik LJ, Striegl RG, McDowell WH, Kortelainen P, Caraco NF, Melack JM, Middelburg JJ (2006) The Global Abundance and Size Distribution of Lakes, Ponds, and Impoundments. Limnol Oceanogr 51 (5):2388-2397

Duc N, Crill P, Bastviken D (2010) Implications of temperature and sediment characteristics on methane formation and oxidation in lake sediments. Biogeochemistry 100 (1):185-196

Dumestre JF, Guézennec J, Galy-Lacaux C, Delmas R, Richard S, Labroue L (1999) Influence of Light Intensity on Methanotrophic Bacterial Activity in Petit Saut Reservoir, French Guiana. Appl Environ Microbiol 65 (2): 534-539

Flanagan KM, McCauley E (2008) Warming and depth interact to affect carbon dioxide concentration in aquatic mesocosms. Freshw Biol 53 (4):669-680

Granato GE (2006) Kendall-Theil Robust Line (KTRLine-version 1.0) - A visual basic program for calculating and graphing robust nonparametric estimates of linear-regression coefficients between two continuous variables. Techniques and Methods of the U.S. Geological Survey, Book 4, Chapter A7. U.S. Geological Survey, Virginia

Gudasz C, Bastviken D, Steger K, Premke K, Sobek S, Tranvik LJ (2010) Temperature-controlled organic carbon mineralization in lake sediments. Nature 466 (7305):478-481

Hamilton JD, Kelly CA, Rudd JWM, Hesslein RH, Roulet NT (1994) Flux to the atmosphere of $\mathrm{CH}_{4}$ and $\mathrm{CO}_{2}$ from wetland ponds on the Hudson Bay lowlands (HBLs). J Geophys Res Atmos. 99 (D1):1495-1510

Helsel DR, Hirsch RM (2002) Statistical methods in water resources. Techniques of Water Resources Investigations, Book 4, Chapter A3. U.S. Geological Survey, Virginia 
Huotari J, Ojala A, Peltomaa E, Pumpanen J, Hari P, Vesala T (2009) Temporal variations in surface water $\mathrm{CO}_{2}$ concentration in a boreal humic lake based on high-frequency measurements. Boreal Environ Res 14:48-60

Huttunen JT, Alm J, Liikanen A, Juutinen S, Larmola T, Hammar T, Silvola J, Martikainen PJ (2003) Fluxes of methane, carbon dioxide and nitrous oxide in boreal lakes and potential anthropogenic effects on the aquatic greenhouse gas emissions. Chemosphere 52 (3):609-621

Juutinen S, Rantakari M, Kortelainen P, Huttunen JT, Larmola T, Alm J, Silvola J, Martikainen PJ (2009) Methane dynamics in different boreal lake types. Biogeosciences 6 (2):209-223

Kortelainen P, Rantakari M, Huttunen JT, Mattsson T, Alm J, Juutinen S, Larmola T, Silvola J, Martikainen PJ (2006) Sediment respiration and lake trophic state are important predictors of large $\mathrm{CO}_{2}$ evasion from small boreal lakes. Glob Change Biol 12 (8):1554-1567

Kosten S, Roland F, Da MM, Van Nes EH, Mazzeo N, Sternberg LdSL, Scheffer M, Cole JJ (2010) Climate-dependent $\mathrm{CO}_{2}$ emissions from lakes. Glob Biogeochem Cycle 24 (2):GB2007

Liikanen A, Murtoniemi T, Tanskanen H, Väisänen T, Martikainen PJ (2002) Effects of temperature and oxygen availability on greenhouse gas and nutrient dynamics in sediment of a eutrophic mid-boreal lake. Biogeochemistry 59 (3):269-286

Marotta H, Duarte CM, Sobek S, Enrich-Prast A (2009) Large $\mathrm{CO}_{2}$ disequilibria in tropical lakes. Glob Biogeochem Cycle 23 (4):GB4022

Mattson MD, Likens GE (1990) Air pressure and methane fluxes. Nature 347 (6295):718-719

Michmerhuizen CM, Striegl RG, McDonald ME (1996) Potential Methane Emission from NorthTemperate Lakes Following Ice Melt. Limnol Oceanogr 41 (5):985-991

Murase J, Sugimoto A (2005) Inhibitory effect of light on methane oxidation in the pelagic water column of a mesotrophic lake (Lake Biwa, Japan). Limnol Oceanogr 50 (4) : 1339-1343

Rantakari M, Kortelainen P (2005) Interannual variation and climatic regulation of the $\mathrm{CO}_{2}$ emission from large boreal lakes. Glob Change Biol 11 (8):1368-1380

Segers R (1998) Methane production and methane consumption: A review of processes underlying wetland methane fluxes. Biogeochemistry 41 (1):23-51 
Sellers P, Hesslein RH, Kelly CA (1995) Continuous measurement of $\mathrm{CO}_{2}$ for estimation of air-water fluxes in lakes: An in situ technique. Limnol Oceanogr 40 (3):575-581

Tranvik LJ, Downing JA, Cotner JB, Loiselle SA, Striegle RG, Ballatore TJ, Dillon P, Finlay K, Fortino K, Knoll LB, Kortelainen PL, Kutser T, Larsen S, Laurion I, Leech DM, McCallister SL, McKnight DM, Melack JM, Overholt E, Porter JA, Prairie Y, Renwick WH, Roland F, Sherman BS, Schindler DW, Sobek S, Tremblay A, Vanni MJ, Verschoor AM, von Wachenfeldt E, Weyhenmeyera GA (2009) Lakes and reservoirs as regulators of carbon cycling and climate. Limnol Oceanogr 54 (6):2298-2314

Utsumi M, Nojiri Y, Nakamura T, Nozawa T, Otsuki A, Seki H (1998) Oxidation of Dissolved Methane in a Eutrophic, Shallow Lake: Lake Kasumigaura, Japan. Limnol Oceanogr 43 (3):471-480-471-480

Van der Nat F, Middelburg JJ, Van Meteren D, Wielemakers A (1998) Diel methane emission patterns from Scirpus lacustris and Phragmites australis. Biogeochemistry 41 (1):1-22

van Hulzen JB, Segers R, van Bodegom PM, Leffelaar PA (1999) Temperature effects on soil methane production: an explanation for observed variability. Soil Biol Biochem 31 (14):1919-1929

Walter KM, Zimov SA, Chanton JP, Verbyla D, Chapin FS (2006) Methane bubbling from Siberian thaw lakes as a positive feedback to climate warming. Nature 443 (7107):71-75

Wiesenburg DA, Guinasso NL (1979) Equilibrium solubilities of methane, carbon monoxide, and hydrogen in water and sea water. J Chem Eng Data 24 (4):356-360

Xing YP, Xie P, Yang H, Ni LY, Wang YS, Rong KW (2005) Methane and carbon dioxide fluxes from a shallow hypereutrophic subtropical Lake in China. Atmos Environ 39 (30):5532-5540

Zhu RB, Liu YS, Xu H, Huang T, Sun JJ, Ma ED, Sun LG (2010) Carbon dioxide and methane fluxes in the littoral zones of two lakes, east Antarctica. Atmos Environ 44 (3):304-311

\section{Figures and tables}


Fig. 1 Total $\mathrm{CH}_{4}$ flux (bars; diffusion is dark grey and ebullition is light grey). The triangles over the bars represent the respective mean air temperature during the period of deployment. Widths of the bars represent the deployment periods

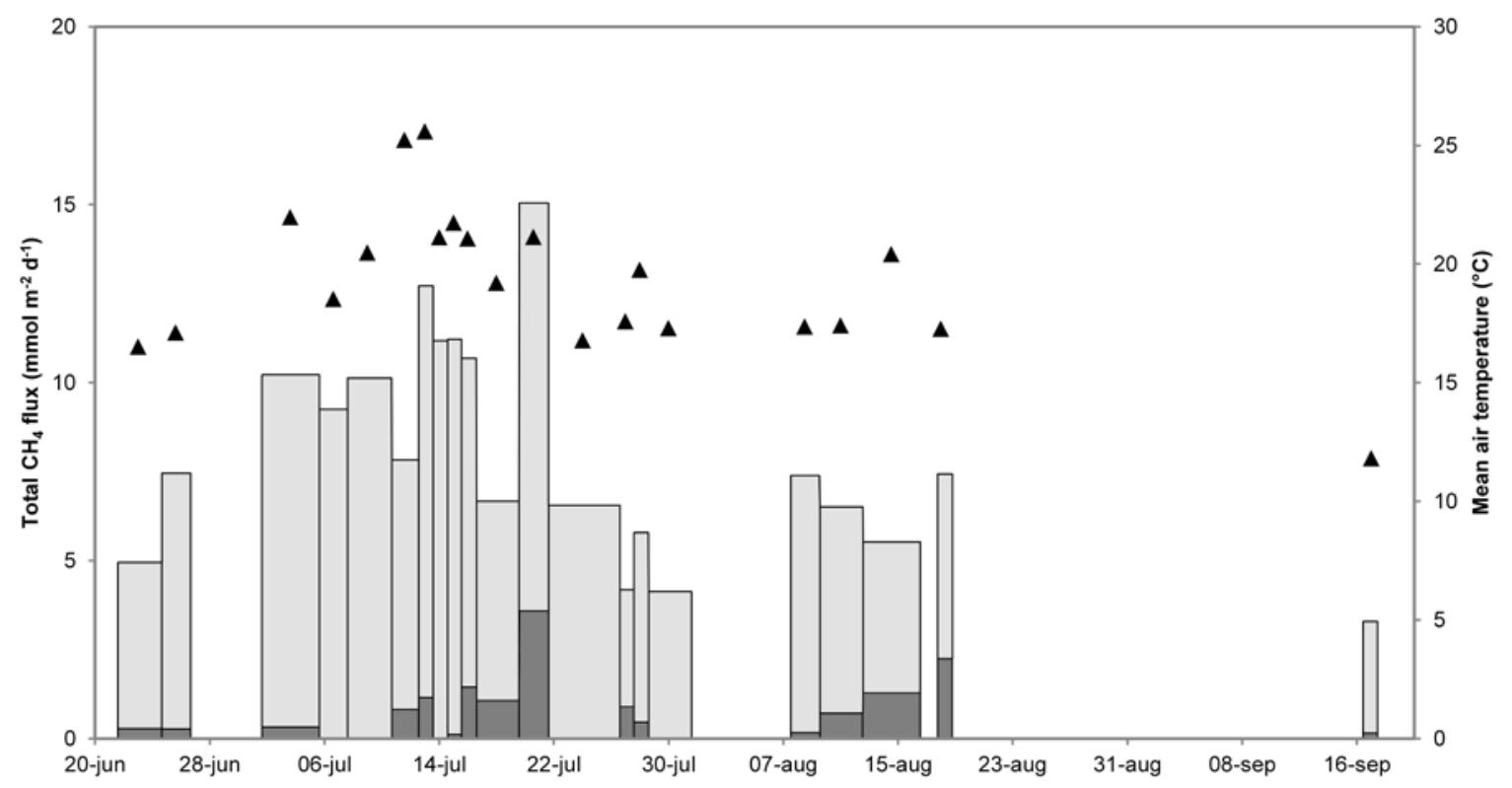

Fig. 2 Relationships between total $\mathrm{CH}_{4}$ flux with mean, maximum air temperature during the chamber deployment period and water temperature during sampling. The dashed and solid lines show the regression for all data or excluding the September data, respectively. The $\mathrm{R}^{2}$ value without the outlier was $0.40,0.25$ and $0.29(\mathrm{p}<0.05)$ for mean air temperature, maximum air temperature and water temperature respectively. Note that average air temperature was integrated over actual deployment periods while water temperatures were single measurements at the end of the measurement periods (see also Discussion). The error bars denote standard deviations (and also the spatial variability in the $\mathrm{CH}_{4}$ fluxes) 

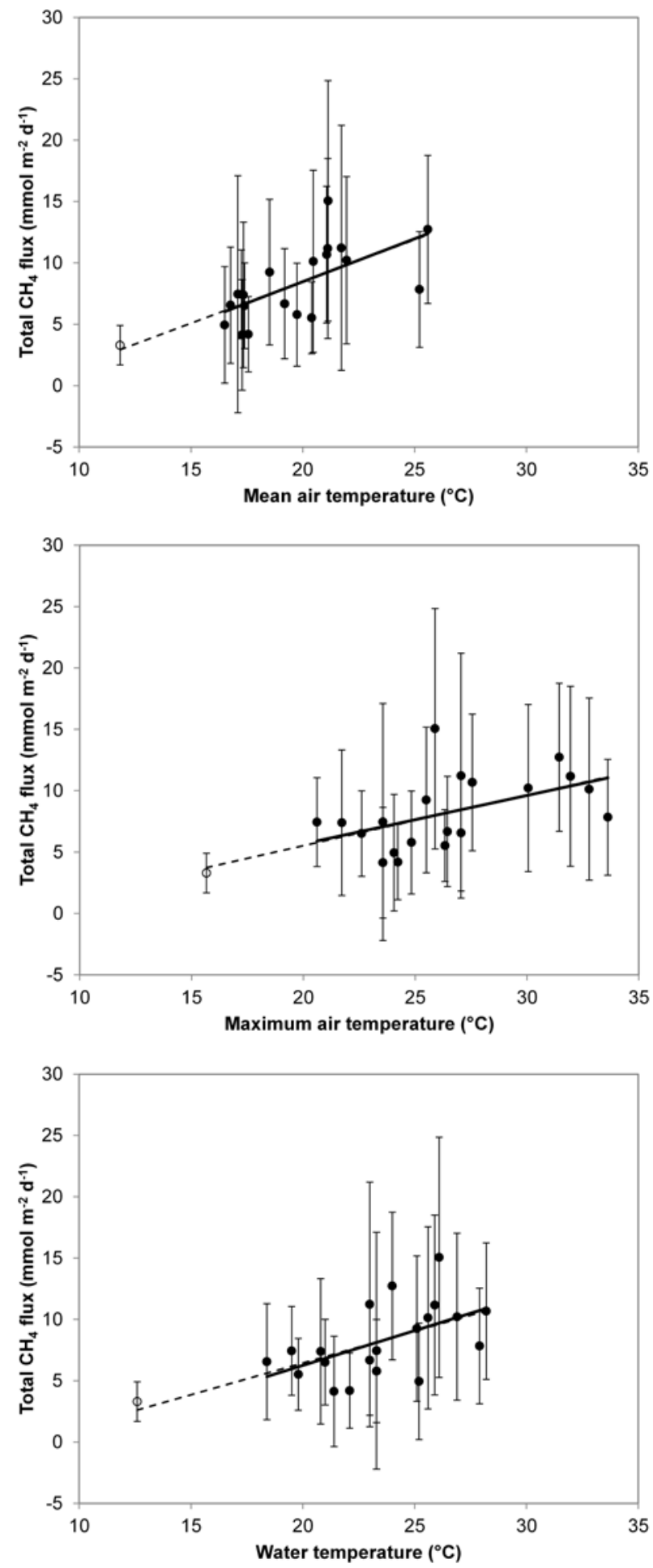
Fig. 3 Diel variation in surface water $\mathrm{CH}_{4}$ concentration (solid line; $\mathrm{n}=3$ ) and $\mathrm{CO}_{2}$ flux (dashed line; $\mathrm{n}=2$ ) measured over a 24-hour period from 18:00 on August 17 to 18:00 on August 18. Error bars represent standard deviations (and were sometimes small enough to be hidden by the symbols)

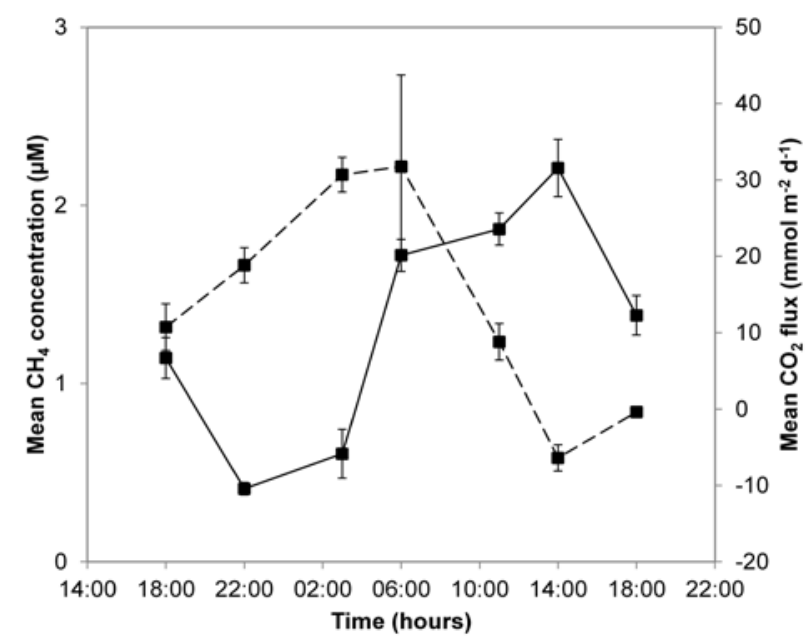

Fig. 4 Relationship between mean $\mathrm{CO}_{2}$ flux $(\mathrm{n}=2)$ and mean solar radiation (mean of 3 hour solar radiation before the measurement)

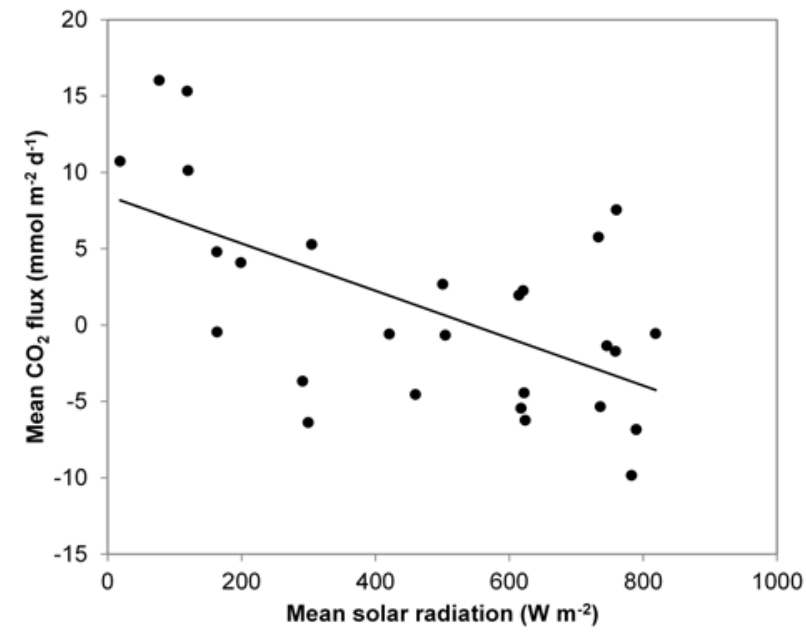


Table 1 Significant relationships between the fluxes and concentrations, respectively, and weather variables

\begin{tabular}{|c|c|c|c|c|c|}
\hline $\begin{array}{c}\text { Model } \\
\text { no. }\end{array}$ & Linear regression & $\mathbf{R}^{2}$ & $p$ & $\begin{array}{l}\text { 95\% confidence } \\
\text { interval (slope) }\end{array}$ & $n^{a}$ \\
\hline \multicolumn{6}{|c|}{$\mathrm{CH}_{4}$ flux } \\
\hline 1 & Total flux $=-5.100+0.679$ mean air temperature ${ }^{\mathrm{b}}$ & 0.47 & 0.001 & $1.024,0.334$ & 21 \\
\hline 2 & Total flux $=-2.732+0.413$ maximum air temperature ${ }^{\mathrm{b}}$ & 0.34 & 0.006 & $0.690,0.135$ & 21 \\
\hline 3 & Total flux $=-3.909+0.518$ water temperature ${ }^{\mathrm{c}}$ & 0.38 & 0.003 & 0.839, 0.197 & 21 \\
\hline 4 & Total flux $=3.881+0.021$ mean solar radiation ${ }^{\mathrm{b}}$ & 0.22 & 0.033 & $0.041,0.002$ & 21 \\
\hline 5 & Mean ebullition $^{\mathrm{d}}=-4.469+0.610$ mean air temperature ${ }^{\mathrm{b}}$ & 0.45 & 0.001 & $0.935,0.285$ & 21 \\
\hline 6 & Mean ebullition $=-3.716+0.423$ maximum air temperature $\mathrm{b}^{\mathrm{b}}$ & 0.42 & 0.002 & $0.663,0.183$ & 21 \\
\hline 7 & Mean ebullition $=-3.790+0.482$ water temperature ${ }^{c}$ & 0.38 & 0.003 & $0.776,0.188$ & 21 \\
\hline 8 & Mean ebullition $=2.928+0.023$ mean solar radiation ${ }^{\mathrm{b}}$ & 0.29 & 0.012 & $0.040,0.006$ & 21 \\
\hline \multicolumn{6}{|c|}{$\mathrm{CO}_{2}$ flux $^{\mathrm{e}}$} \\
\hline 9 & Mean $\mathrm{CO}_{2}$ flux $^{\mathrm{f}}=15.286-0.650$ air temperature ${ }^{\mathrm{c}}$ & 0.28 & 0.004 & $-0.222,-1.077$ & 27 \\
\hline 10 & Mean $\mathrm{CO}_{2}$ flux $=18.840-0.811$ water temperature ${ }^{\mathrm{C}}$ & 0.32 & 0.002 & $-0.327,-1.294$ & 27 \\
\hline 11 & Mean $\mathrm{CO}_{2}$ flux $=8.445-0.016$ mean solar radiation ${ }^{\mathrm{g}}$ & 0.36 & 0.001 & $-0.007,-0,024$ & 27 \\
\hline $\begin{array}{c}\text { Model } \\
\text { no. }\end{array}$ & Kendall-Theil Robust Line & $\begin{array}{c}\text { Kendall's } \\
\tau\end{array}$ & $p$ & $\begin{array}{l}\text { 95\% confidence } \\
\text { interval (slope) }\end{array}$ & $n^{a}$ \\
\hline \multicolumn{6}{|c|}{ Surface water $\mathrm{CH}_{4}$ concentration ${ }^{\mathrm{e}}$} \\
\hline 12 & $\mathrm{CH}_{4}$ concentration $=36.99-0.036$ mean pressure ${ }^{\mathrm{h}}$ & -0.22 & 0.036 & $-0.002,-0.068$ & 47 \\
\hline 13 & $\mathrm{CH}_{4}$ concentration $=1.204-0.003$ mean solar radiation ${ }^{\mathrm{h}}$ & -0.25 & 0.014 & $-0.001,-0.005$ & 47 \\
\hline 14 & $\mathrm{CH}_{4}$ concentration $=2.069-0.062$ water temperature ${ }^{\mathrm{c}}$ & -0.29 & 0.005 & $-0.013,-0.133$ & 47 \\
\hline 15 & $\mathrm{CH}_{4}$ concentration $=0.801+0.173$ max precipitation ${ }^{\mathrm{h}}$ & 0.25 & 0.022 & $0.300,0.020$ & 47 \\
\hline 16 & $\mathrm{CH}_{4}$ concentration $=2.770-0.112$ mean air temperature ${ }^{\mathrm{h}}$ & -0.34 & 0.001 & $-0.020,-0.221$ & 47 \\
\hline
\end{tabular}

For normally distributed data linear regression was used. Non- normal data were analyzed using the Kendall-Theil robust line method. Units of the dependent and independent variables: temperature $\left({ }^{\circ} \mathrm{C}\right)$, 
pressure (hPa), solar radiation $\left(\mathrm{W} \mathrm{m}^{-2}\right)$, precipitation $(\mathrm{mm})$, total $\mathrm{CH}_{4}$ flux and ebullition ( $\mathrm{mmol} \mathrm{m}^{-2} \mathrm{~d}^{-}$ ${ }^{1}$ ), surface water $\mathrm{CH}_{4}$ concentration $(\mu \mathrm{M})$ and $\mathrm{CO}_{2}$ flux $\left(\mathrm{mmol} \mathrm{m}^{-2} \mathrm{~d}^{-1}\right)$.

${ }^{a}$ number of observations; for $\mathrm{CH}_{4}$ and $\mathrm{CO}_{2}$ flux, it denotes the number of sampled occasions and for $\mathrm{CH}_{4}$ concentration, the number of measurements

${ }^{\mathrm{b}}$ regressions with the weather variables during the period of chamber deployment

${ }^{\mathrm{c}}$ regressions with the weather variables at the time of sampling

${ }^{\mathrm{d}}$ mean ebullition from the chambers that received ebullition

${ }^{\mathrm{e}}$ relationships based on daytime (between 10:15 to 19:00) values; most of them were between 12 to 15

${ }^{\mathrm{f}}$ mean of $\mathrm{CO}_{2}$ flux from two replicates

${ }^{\mathrm{g}}$ mean solar radiation of 3 hours before sampling

${ }^{\mathrm{h}}$ regressions with variables 24 hours before the sampling 